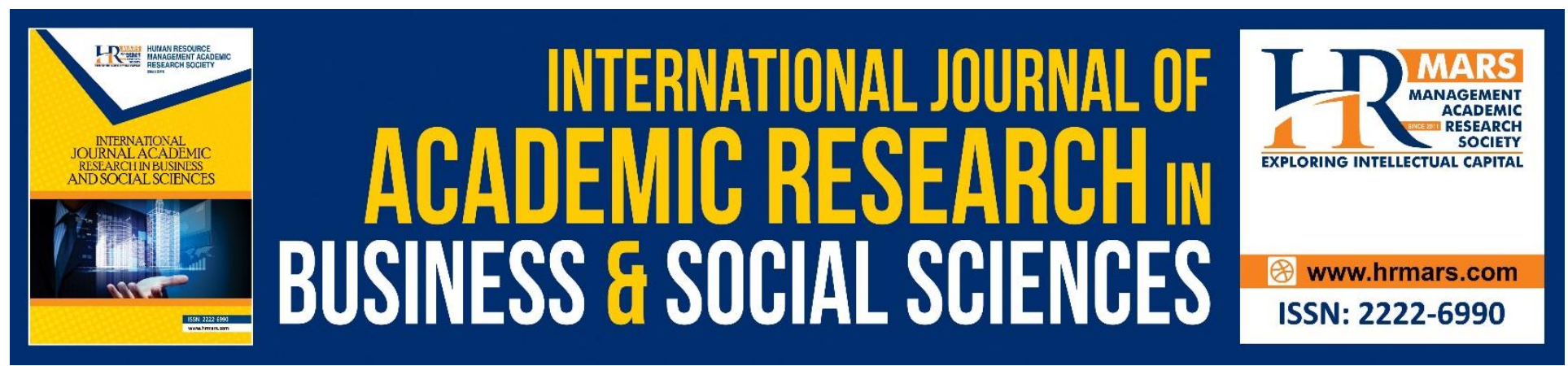

\title{
The Impact of the Leadership of the Head of Department on Administrative Staff's Performance in Malaysian Premier Education University
}

Suzyanty Mohd Shokory, Suriani Abdul Hamid, Marinah Awang, Norlaile Salleh Hudin

To Link this Article: http://dx.doi.org/10.6007/IJARBSS/v9-i3/5624

DOI: $\quad 10.6007 /$ IJARBSS/v9-i3/5624

Received: 21 Feb 2019, Revised: 14 March 2019, Accepted: 29 March 2019

Published Online: 08 April 2019

In-Text Citation: (Shokory, Hamid, Awang, \& Hudin, 2019)

To Cite this Article: Shokory, S. M., Hamid, S. A., Awang, M., \& Hudin, N. S. (2019). The Impact of the Leadership of the Head of Department on Administrative Staff's Performance in Malaysian Premier Education University. International Journal of Academic Research in Business and Social Sciences, 9(3), 27-42.

Copyright: (c) 2019 The Author(s)

Published by Human Resource Management Academic Research Society (www.hrmars.com)

This article is published under the Creative Commons Attribution (CC BY 4.0) license. Anyone may reproduce, distribute, translate and create derivative works of this article (for both commercial and non-commercial purposes), subject to full attribution to the original publication and authors. The full terms of this license may be seen at: http://creativecommons.org/licences/by/4.0/legalcode

Vol. 9, No. 3, 2019, Pg. 27 - 42

http://hrmars.com/index.php/pages/detail/IJARBSS

JOURNAL HOMEPAGE

Full Terms \& Conditions of access and use can be found at http://hrmars.com/index.php/pages/detail/publication-ethics 


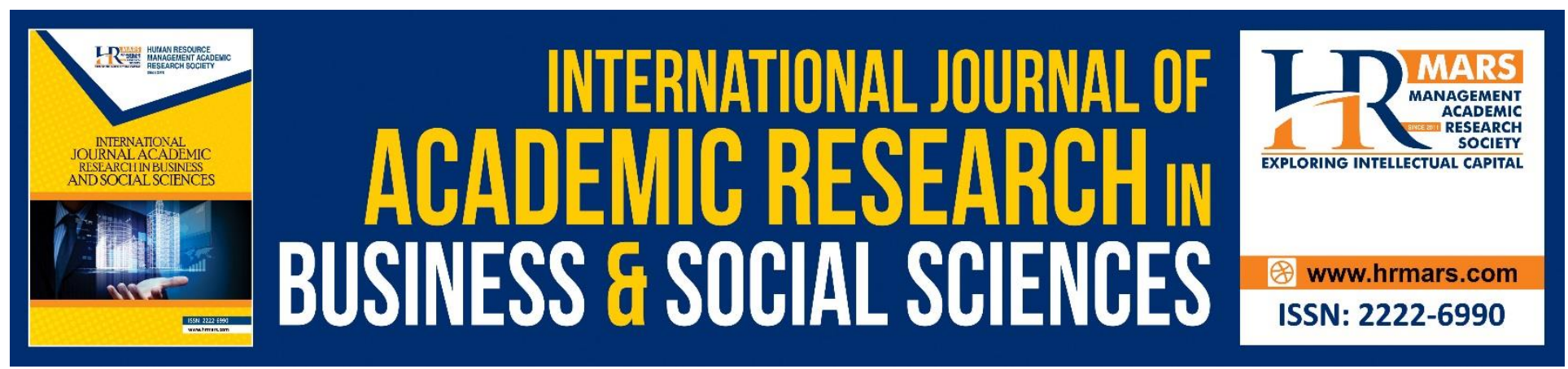

\title{
The Impact of the Leadership of the Head of Department on Administrative Staff's Performance in Malaysian Premier Education University
}

\author{
Suzyanty Mohd Shokory, Suriani Abdul Hamid, Marinah Awang, \\ Norlaile Salleh Hudin \\ Universiti Pendidikan Sultan Idris, Malaysia
}

\begin{abstract}
The purpose of this study was to examine the impact of the leadership style of the head in department through the three types of leadership styles practiced which were transformational, transactional and laissez-faire leadership on the performance of administrative staff in one of the premier education universities in Malaysia. In addition, this study also sought to identify which leadership style of the head in department was a more dominant predictor on the performance of the administrative staff when the leadership styles (transformational, transactional and laissez-faire) were analyzed simultaneously. The quantitative approach was utilized in this study. The sample survey method was carried out involving 234 administrative staff as the respondents of the study. The sample was selected by using the simple random sampling technique and the data was collected using questionnaires. The data analysis was conducted using the Statistical Packages for Social Science (SPSS) involving descriptive analysis (frequency and percentage). Hierarchical Linear Modeling (HLM) version 7 software was used to perform multi-level analysis as the nature of the study data involved various levels of individual data nested (groups) in the organization. The analysis showed that transformational, transactional and laissez-faire leadership of the head in department was a positive significant with the in-role and extra-role performance of the administrative staff when analyzed separately. However, when the transformational, transactional and laissez-faire leadership of the head in department were analyzed simultaneously, they clearly showed that all these three leadership styles did not influence the in-role performance of the administrative staff. Interestingly in this study, only transformational leadership of the head of department proved a dominant influence on the extra-role performance of administrative staff compared to transactional and laissez-faire leadership. The findings of this study provided empirical evidence that although transformational, transactional and laissez-faire leadership of head of department could improve the in-role and extra-role performance of the administrative staff, this study proved that
\end{abstract}


INTERNATIONAL JOURNAL OF ACADEMIC RESEARCH IN BUSINESS AND SOCIAL SCIENCES

Vol. 9, No. 3, March, 2019, E-ISSN: $2222-6990$ (C) 2019 HRMARS

transformational leadership of the head of department could move to extra-role performance compared to other leadership styles.

Keywords: Leadership, Head of Department, Performance, Administrative Staff, Premier Education University

\section{Introduction}

Education is a nation's asset in forming and producing quality human capital who can compete with other citizens of the world. As such, the education system in Malaysia has undergone expansion and change to meet global market demands (Mohd Mahzan, Abdul Razaq \& Manisah, 2013).

The increase in the establishment of the number of public higher education institutions (IPTA) and private higher education institutions (IPTS) in recent years in Malaysia (Ahsan et al., 2009) illustrates that Malaysia is also competing in the era of education globalization. One of the IPTAs that took up the challenge of education globalization is a Malaysian premier education university. The university holds the privilege of becoming the number one education university in the region.

To ensure that this premier education university is the number one and top education university in the region, various strategies and actions have been taken and many challenges have been faced by university management to compete with other universities and to remain at the forefront in the industry (Ahsan et al., 2009; Sabharwal \& Corley, 2009). Support and commitment from all university members from the management, academic staff or administrative staff is essential to ensure its excellence as a top education institution.

The administrative staff in educational organizations play a significant role in supporting the vision and mission of the top management. Therefore, every administrative staff should ensure that his/her performance is in good standing so that the university's aim to become the number one and superior education university in the region is achieved. Based on the statistics, it was found that the percentage of the administrative staff in one of the Malaysian premier education university who had scored less than 70 marks in their performance was 8.63 per cent in 2015 compared to only 5.40 per cent in 2014 . This has raised the question to the researchers: are the performance scores of these administrative staff influenced by the leadership style practised by the head of department or are they caused by other factors?

The findings from previous empirical studies have shown that leadership is a key factor in determining the excellence of an organization. This can be clearly seen when leadership variables are often studied to see the impact on the performance of the workers (Walumbwa \& Hartnell, 2011). Next, Fry (2003) explains that leadership aspects can indirectly motivate workers to increase the potential and development of workers. Samsudin et al., (2016) also emphasized that the leaders' behaviour needs to be studied as it can help leaders and organizations to maximize resources used to enable the organizational operations to be more efficient.

Erkutlu (2008) assumes that organizations need to understand the nature of leadership behaviour and identify effective leadership styles as well as appropriate for the level of management and by type of work. In addition, the organization also needs to ensure that 
management's leadership style matches the needs of the organization and take corrective measures if circumstances require it (Thacker \& Holl, 2008). Thacker and Holl (2008) suggest that each study should focus on employee perceptions on behaviour and management leadership style to ensure employee satisfaction and the effectiveness of management functions within an organization. Hence, the appropriate leadership style should be practiced by every organizational leader to ensure the success and excellence of an organization and with the support and cooperation of other members or employees in the organization to achieve the goals set.

Most empirical studies on leadership have only focused on the immediate impact of leader leadership on the conduct of individual employees (Yammarino \& Dansereau, 2008). Based on previous empirical studies, not much research has been conducted to test the different leadership styles practised by leaders which affect the performance of workers. Therefore, this study attempts to overcome this gap by examining the three types of leadership (transformational, transaction and laissez-faire leadership) practised by the head of department simultaneously to identify which leadership style is more dominant in influencing the in-role and extra-role performances of the administrative staff. Interestingly in this study, the in-role and extra-role performances of administrative staff are examined as a previous study has narrowed down on the use of these two types of performances in determining the worker's performance. Past studies only looked at the overall employee performance in measuring the performance of their employees.

Although leadership is characterized by multi-level features, empirical studies of leadership and multi-level results are limited. Therefore, the leadership phenomena need to be studied using multi-level approaches) (Mathieu \& Taylor, 2007) to provide a better understanding of the impact of leadership variables within the organization. Based on the descriptions described above, the study aimed to test the dominant leadership style of the head of department (transformational, transactional or laissez-faire leadership) at the team level which is a predictor of in-role and extrarole performances of administrative staff at individual level at one of the premier education universities available in Malaysia. The Multi-level Modelling Analysis approach using HLM (hierarchical linear modelling) version 7.0 was used in this study to determine how the leadership of the different heads of department influenced in-role and extra-role performances of administrative staff in a complex multi-level modelling system. The HLM software was used in this study as it could estimate the impact of constructs at different levels on the yield constructs at the individual level simultaneously (Raudenbush, Bryk \& Congdon, 2005; Raudenbush, et all. 2011).

\section{Literature Review}

Leadership has become a major focus in the field of organizational behaviour as it creates one of the dynamic effects of the interaction between individuals and organizations (Obiwuru, Okwu, \& Akpa, 2011). It is also an important factor in determining the success or failure of an organization (Long \& Thean, 2011). Leadership can generally be defined as a process of interaction between leaders and followers (Northouse, 2010) and influences the followers to achieve defined organization goals (Tetteh \& Brenyah, 2016). 
There are various leadership styles used by leaders in previous empirical studies (Hirtz, Murray, \& Riordan, 2007) but the leadership style that a person applies to a leader will vary depending on the different situations (Khan et al., 2015) in order to manage members of the organization to produce positive results (Tetteh \& Brenyah, 2016). In this study, transformational, transactional and laissez faire leadership approaches had been used to see the impact on the performance of administrative staff.

Bass (1985) states transformational leadership as one of the most commonly used approaches to identify the effectiveness of individuals, groups and organizations. Transformational leadership involves four dimensions: individualized consideration, intellectual stimulation, idealized influence and inspirational motivation. Transformation leadership is said to fulfil its intrinsic satisfaction and the development of its followers (Bass \& Avolio, 1995), inspiring the followers to perform more than they were suggested (Bass \& Riggio, 2006) and emphasizing every member of the team (Yang, Wu, \& Huang, 2013).

Transactional leaders focus on the basis of the 'exchange transaction' between leader and subordinates by offering rewards (or giving punishments) for the performance of desired behaviours and the completion of certain tasks (Megat Zuhairy, Hadijah \& Noraini, 2015). There are three dimension involved in transactional leadership: contingent reward, active management by exception and passive management by exception (Bass \& Avolio, 1995). Transactional leaders involve managing in the more conventional sense of clarifying subordinate responsibilities, rewarding them for meeting performance objectives (Yang et al., 2013), and correcting them for failing to meet objectives (Eagly, Johannesen-Schmidt \& Van Engen, 2003). Transactional leaders emphasize contingent rewards and show how current needs of subordinates can be satisfied (Yang et al., 2013).

Koech and Namusonge (2012) define laissez-faire leadership style as being associated with unproductiveness, ineffectiveness and dissatisfaction. The laissez-faire leadership style is also known as the "hands-off "style. It is one in which the manager provides little or no direction and gives employees as much freedom as possible. All authority or power is given to the employees and they must determine goals, make decisions and resolve problems on their own (Khan et al., 2015).

In-role performance is defined as the officially required outcome and behavior that directly serves the goals of the organization (Motowidlo \& Van Scotter, 1994). On the other hand, extrarole performance is defined as a discretionary behavior on the part of an employee which is believed to directly promote the effective functioning of an organization, without necessarily directly influencing a person's target productivity (Posdakoff \& MacKenzie, 1994). For this study, in-role performance refers to the behavior of administrative staff performed as officially recognized by the organizational system while extra-role performance refers to the behavior of an administrative staff who 'goes the extra mile' and facilitates the achievement of the organization's mission and success. 
Based on the explanation above, there are clear differences between transformational, transactional and laissez-faire leadership in influencing the performance of individuals and organizations including the administrative staff. In order to ensure the performance of the organization and employees achieved according to the goals set, every organization needs a good leader who is efficient in achieving that goal.

Hence, the head of department as the leader in the organization should carry out this leadership trust with dedication as he/she is the individual responsible for all activities carried out in each department. Studies have proven that leadership is positively related to the performance of employees (Walumbwa \& Hartnell, 2011). In this study, the leadership of each head of department at the top level which included the transformational, transactional and laissez-faire leadership styles was analyzed to see the effects on in-role and extra-role performances of the individual (individual level) at the lower level. In addition, this study also aimed to identify the leadership style practised by the head in each department and its dominance in influencing inrole and extra-role performances of the administrative staff.

Therefore, six hypotheses had been developed to answer the research question of the study as the following:

Hypotheses 1: Transformational leadership of head of department at team level is positively related to the in-role performance of administrative staff at individual level.

Hypotheses 2: Transactional leadership of head of department at team level is positively related to the in-role performance of administrative staff at individual level.

Hypotheses 3: Laissez- faire leadership of head of department at team level is positively related to the in-role performance of administrative staff at individual level.

Hypotheses 4: Transformational leadership of head of department at team level is positively related to the extra-role performance of administrative staff at individual level.

Hypotheses 5: Transactional leadership of head of department at team level is positively related to the extra-role performance of administrative staff at individual level.

Hypotheses 6: Laissez- faire leadership of head in department at team level is positively related to the extra-role performance of administrative staff at individual level. 
Figure 1: Research Model Based on Six Hypotheses Stated Above.

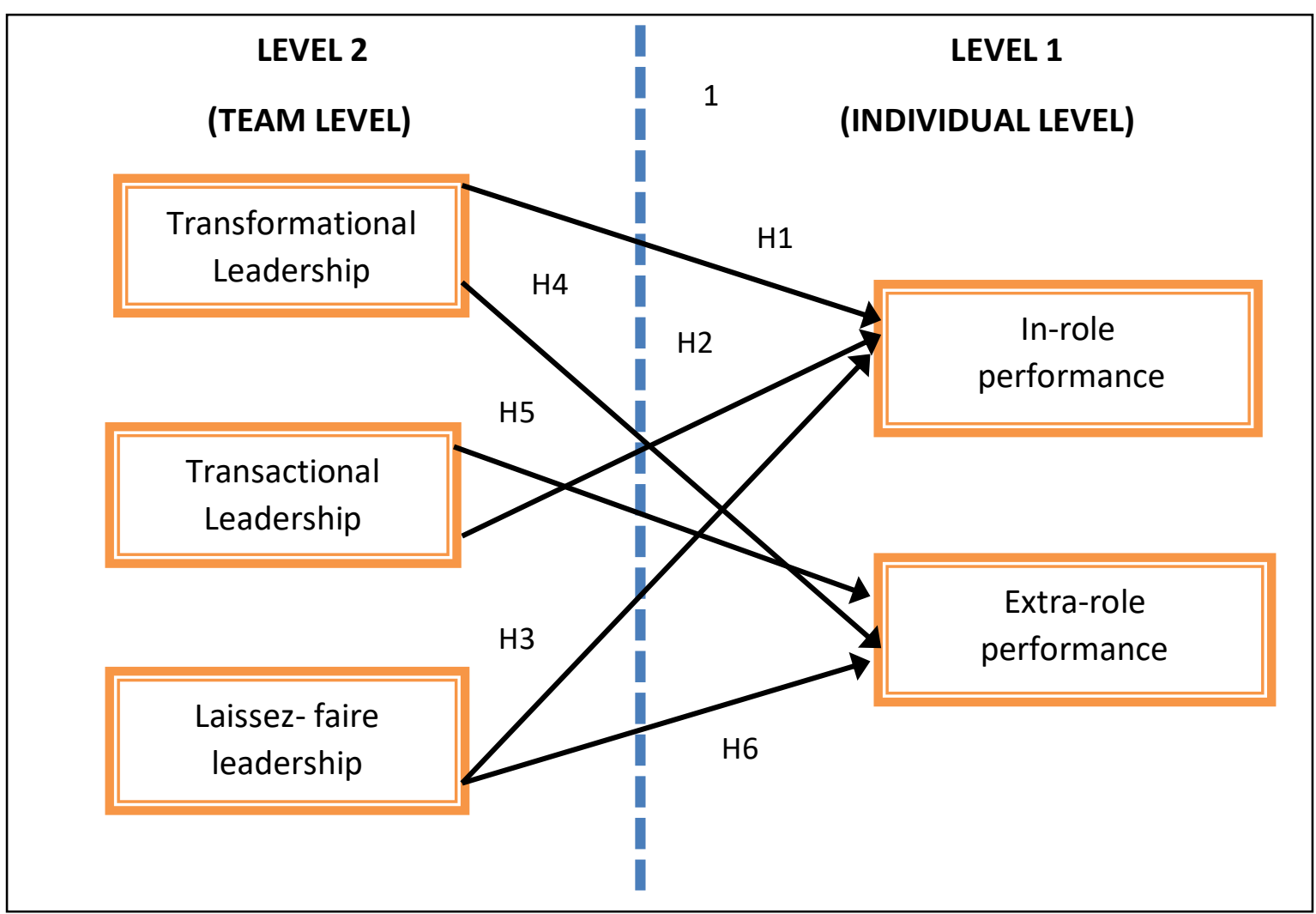

\section{Methodology \\ Samples}

The study sample comprised 234 administrative staff from 37 department in one of the premier education universities in Malaysia. The administration staff who were involved in this study consisted of staff from the Management and Professional Group and the Supporting Staff Group. To utilise a Multilevel Modelling analysis, the researcher needed at least 30 organizations for the study (Kreft \& De Leeuw, 1998) with a minimum of 5 samples from each organization (Maas \& Hox, 2005). Therefore, the number of samples involved were sufficient and adequate for the study.

\section{Instruments}

Transformational, transactional and laissez- faire leadership styles of the head of department were measured using a questionnaire Multifactor Leadership Questionnaire (MLQ) (Bass \& Avolio, 2000). A total of 20 items in MLQ had been used to measure the transformational leadership style involving five dimensions of idealized influence-attribute, idealized influence, behaviour, inspirational motivation, intellectual stimulation and individualized consideration. There were 12 items used to measure transactional leadership where every dimension involved four measurement items. The three dimensions consisted of contingent reward, management by exception, and active-passive management by exception. On the other hand, only four items in 
MLQ had been used to measure the laissez-faire leadership style. The participants rated these items on a 5-point Likert scale ranging from 0 (never) to 4 (always).

The in- role and extra-role performances were measured using an instrument previously used by Goodman \& Svyantek (1999). A total of 16 items had been used to measure the administrative staff's performance which consisted of nine items for measuring the in-role performance and seven items to measure extra-role performance. All these items were scored on five-point scales ranging from strongly disagree to (5) strongly agree.

\section{Analysis Procedure}

To test all the hypotheses contained in this study, the data for the current study was analysed using the Hierarchical Linear Modelling (HLM) software version 7.0 (Raudenbush et all., 2005). In this study, the data for variables at the individual level (Level 1) referring to the administrative staff and the variables at the team level (Level 2) referring to the head of department were standardized between these two levels as suggested by Mathieu and Taylor (2007).

\section{Aggregation Procedure}

To determine whether the leadership of the head of each department could be aggregated to the team level, two tests needed to be conducted such as the Inter-rater reliability test ( $(\mathrm{wg})$ ) and the Intra-class coefficient test (ICC 1). The Inter-rater reliability test ( $($ (wg)) was used to justify the existence of an aggregate score at the team level while the Intra-class coefficient test (ICC 1 ) was used to assess organizational variance. After the two tests achieved the cut of point as suggested, the F-test needed to be conducted and the result obtained should be significant. The F-test would indicate whether the average scores differed significantly across teams.

\section{Results}

Table 1 below summarizes the respondents' demographic profile. The respondents in this current study comprised 234 administrative staff members from 37 departments. Each respondent was given a self-rated questionnaire to complete. The respondents comprised 112 males (47.90\%) and 122 females (52.10\%) and 128 of them were from the age range of 30 to 39 years (54.70\%). Regarding their education level, 106 or most of them were Certificate / Diploma holders (45.30\%). In total, 119 of the respondents were in the supporting staff group 2 (50.90\%), $32.50 \%$ were in the supporting staff group 1 and $16.70 \%$ were in the management and professional group. In term of status position, $84.20 \%$ (197) of the respondents were permanent staff members and $15.80 \%$ (37) were contract staff members. In addition, most of the respondents had been in employment for 1 to 10 years $(58.90 \%)$. 
Table 1: Respondent's Demographic Profile

\begin{tabular}{|c|c|c|c|}
\hline \multicolumn{2}{|c|}{ Demographic } & \multirow{2}{*}{$\begin{array}{c}\text { Frequency }(\mathbf{N}) \\
112\end{array}$} & \multirow{2}{*}{$\begin{array}{c}\text { Percentage (\%) } \\
47.90\end{array}$} \\
\hline Gender & Male & & \\
\hline & Female & 122 & 52.10 \\
\hline \multirow[t]{8}{*}{ Age } & $20-24$ years & 15 & 6.40 \\
\hline & 25 - 29 years & 47 & 20.10 \\
\hline & $30-34$ years & 74 & 31.60 \\
\hline & 35 - 39 years & 54 & 23.10 \\
\hline & $40-44$ years & 26 & 11.10 \\
\hline & 45 - 49 years & 12 & 5.10 \\
\hline & 50 - 54 years & 3 & 1.30 \\
\hline & More than 55 years & 3 & 1.30 \\
\hline \multirow[t]{4}{*}{ Education level } & Secondary School & 35 & 15.00 \\
\hline & Certificate / Diploma & 106 & 45.30 \\
\hline & Bachelor Degree & 68 & 29.10 \\
\hline & Masters / PhD & 25 & 10.70 \\
\hline \multirow[t]{6}{*}{ Current Position } & Management and & 39 & 16.70 \\
\hline & Professional Group & & \\
\hline & Supporting Actions & 76 & 32.50 \\
\hline & Group 1 & & \\
\hline & Supporting Actions & 119 & 50.90 \\
\hline & Group 2 & & \\
\hline \multirow[t]{2}{*}{ Status Position } & Permanent & 197 & 84.20 \\
\hline & Contract & 37 & 15.80 \\
\hline \multirow{7}{*}{$\begin{array}{l}\text { Duration of service in } \\
\text { the current } \\
\text { organization }\end{array}$} & $1-5$ years & 60 & 25.60 \\
\hline & $6-10$ years & 78 & 33.30 \\
\hline & $11-15$ years & 54 & 23.10 \\
\hline & $16-20$ years & 30 & 12.80 \\
\hline & $21-25$ years & 10 & 4.30 \\
\hline & $26-30$ years & 1 & 0.40 \\
\hline & More than 30 years & 1 & 0.40 \\
\hline
\end{tabular}

Table 2 reports the means, standard deviations and inter-correlations between variables at individual and team level, the $F$ values and intra-class coefficients, ICC (1).

Table 3 shows the results of the cross-level analysis using HLM. In this study, cross-level analysis involved transformational, transactional and laissez-faire leadership styles of the head of department constructs at the upper level of the in-role and extra-role performance of administrative staff construct at the lower level. 
Based on the analysis in Table 3, we found that transformational leadership (Model 1$)(\gamma=0.220$, $\mathrm{SE}=0.09, \mathrm{t}=2.493, \mathrm{p}<0.001)$, transactional leadership (Model 2$)(\gamma=0.394, \mathrm{SE}=0.06, \mathrm{t}=6.872$, $p<0.001)$ and laissez- faire leadership (Model 3$)(\gamma=0.359, S E=0.07, t=4.861, p<0.001)$ of head of department at the team level were positively related to the in-role performance of administrative staff at the individual level when the analysis was done separately. In addition, we also found that the transformational leadership (Model 5) $(\gamma=0.293, \mathrm{SE}=0.09, \mathrm{t}=3.428, \mathrm{p}=$ $0.002)$, transactional leadership (Model 6$)(\gamma=0.472, \mathrm{SE}=0.07, t=6.502, p<0.001)$ and laissezfaire leadership (Model 7) $(\gamma=0.419, \mathrm{SE}=0.09, \mathrm{t}=4.642, \mathrm{p}<0.001$ ) of head of department at the team level were positively related to extra-role performance of administrative staffs at individual level when the analysis was done separately.

Surprisingly, when the analysis was done simultaneously to the transformational, transactional and laissez-faire leadership of the head of department at the team level on in-role and extra-role performance of administrative staffs at the individual level, we found that the findings were different when the analysis was done separately (refer to Model 4 and Model 8 in Table 3).

Table 2: Means, Standard Deviations and correlations between variables, F and ICC (1) Values

$\begin{array}{llllllllll}\text { Variables } & M & \text { SD } & 1 & 2 & 3 & 4 & 5 & \text { F } & \text { ICC }\end{array}$

\begin{tabular}{|c|c|c|c|c|c|c|c|c|c|}
\hline $\begin{array}{l}\text { 1. Transformational } \\
\text { leadership }\end{array}$ & 2.094 & 1.125 & 1 & & & & & $1.741^{* *}$ & 0.187 \\
\hline $\begin{array}{l}\text { 2. Transactional } \\
\text { leadership }\end{array}$ & 2.762 & 0.482 & $0.858 * * *$ & 1 & & & & $1.761^{* *}$ & 0.152 \\
\hline $\begin{array}{l}\text { 3. Laissez- faire } \\
\text { leadership }\end{array}$ & 2.897 & 0.528 & $0.180 * *$ & $0.331 * * *$ & 1 & & & $3.032 * * *$ & 0.246 \\
\hline $\begin{array}{l}\text { 4. In-role } \\
\text { performance }\end{array}$ & 3.970 & 0.667 & $0.299 * * *$ & $0.307 * * *$ & $0.174 * * *$ & 1 & & $3.288 * * *$ & 0.274 \\
\hline $\begin{array}{l}\text { 5. Extra-role } \\
\text { performance }\end{array}$ & 4.144 & 0.685 & $0.314^{* * *}$ & $0.319 * * *$ & $0.228 * * *$ & $0.795^{* * *}$ & 1 & $3.486 * * *$ & 0.289 \\
\hline
\end{tabular}

Note: Bivariate correlations only between lower level variables. ( $N=234,37$ departments) $\mathrm{M}=$ Mean; SD = Standard Deviation

$* \mathrm{p}<0.05, \quad * * \mathrm{p}<0.01, \quad * * * \mathrm{p}<0.001$

Hypothesis 1 proposed that the transformational leadership of head in department at the team level was positively related to the in-role performance of administrative staff at individual level. The result showed that hypothesis 1 was not supported as transformational leadership of head of department at the team level was not significantly related to the in-role performance of administrative staff at the individual level $(\gamma=0.122, \mathrm{SE}=0.123, \mathrm{t}=0.994$, n.s.).

Thus, hypothesis 2 proposed that the transactional leadership of head of department at the team level was positively related to the in-role performance of administrative staff at the individual level. As indicated in Model 2, we found that hypothesis 2 was not supported as transactional 
leadership of head of department at the team level was not significantly related to the in-role performance of administrative staff at the individual level $(\gamma=149, \mathrm{SE}=0.211, t=0.705$, n.s. $)$.

Hypothesis 3 proposed that the laissez-faire leadership of head of department at the team level was positively related to the in-role performance of administrative staff at the individual level. The result showed that hypothesis 3 was not supported as the laissez-faire leadership of head of department at the team level was not significantly related to the in-role performance of the administrative staff at the individual level $(\gamma=218, \mathrm{SE}=0.196, \mathrm{t}=1.112$, n.s.).

The relationship between the transactional and laissez- faire leadership styles of the head of department at the team level on the extra-role performance of administrative staff at the individual level was not significant. Surprisingly, the findings indicated that only the transformational leadership of the head of department at the team level on the extra-role performance of administrative staff at the individual level was significant. Hypothesis 5 which proposed that the transformational leadership would be positively related to extra-role performance was supported $(\gamma=0.193, \mathrm{SE}=0.08, \mathrm{t}=2.361, \mathrm{p}=0.024)$, indicating that the increasing level of transformational leadership of the head of department would also increase the extra-role performance of the administrative staff. On the other hand, transactional and laissez- faire leadership styles were found not to be positively related to the extra-role performance as Hypothesis $6(\gamma=0.145, \mathrm{SE}=0.160, t=0.909, \mathrm{n} . \mathrm{s}$. $)$ and Hypothesis $7(\gamma=0.272$, $\mathrm{SE}=0.156, \mathrm{t}=1.747, \mathrm{n} . \mathrm{s}$.) were not supported by the analysis.

\section{Discussion}

In general, the present study provides an insightful understanding of transformational, transactional and laissez- faire leadership styles of the head of department and the influence on the in-role and extra-role performance of administrative staffs. This study discovered that transformational, transactional and laissez-faire leadership styles of the head of department at the team level was able to influence the in-role and extra-role performances of the administrative staff. We used multilevel analysis to examine the effect of transformational, transactional and laissez- faire leadership styles of the head in department on the in-role and extra-role performance of administrative staffs. 
INTERNATIONAL JOURNAL OF ACADEMIC RESEARCH IN BUSINESS AND SOCIAL SCIENCES

Vol. 9, No. 3, March, 2019, E-ISSN: 222 2-6990 @ 2019 HRMARS

Table 3: HLM Analyses of Cross-Level Effect on Lower Level Outcomes

\begin{tabular}{|c|c|c|c|c|c|c|c|c|}
\hline Effect & $\begin{array}{c}\text { In-role } \\
\text { performanc } \\
\text { e }\end{array}$ & $\begin{array}{c}\text { In-role } \\
\text { performance }\end{array}$ & $\begin{array}{c}\text { In-role } \\
\text { performanc } \\
\text { e }\end{array}$ & $\begin{array}{c}\text { In-role } \\
\text { performanc } \\
\text { e }\end{array}$ & $\begin{array}{c}\text { Extra-role } \\
\text { performanc } \\
\text { e }\end{array}$ & $\begin{array}{c}\text { Extra-role } \\
\text { performanc } \\
\text { e }\end{array}$ & $\begin{array}{c}\text { Extra-role } \\
\text { performanc } \\
\text { e }\end{array}$ & $\begin{array}{c}\text { Extra-role } \\
\text { performanc } \\
\text { e }\end{array}$ \\
\hline Model & 1 & 2 & 3 & 4 & 5 & 6 & 7 & 8 \\
\hline \multicolumn{9}{|l|}{ Cross-Level Effect } \\
\hline $\begin{array}{c}\text { Transformational } \\
\text { leadership }\end{array}$ & $\begin{array}{c}0.220 \\
(0.09)^{*}\end{array}$ & & & $\begin{array}{c}0.122 \\
(0.123)^{n . s .}\end{array}$ & $\begin{array}{c}0.293 \\
(0.09)^{* *}\end{array}$ & & & $\begin{array}{c}0.193 \\
(0.08)^{*}\end{array}$ \\
\hline Transactional leadership & & $\begin{array}{c}0.394 \\
(0.06)^{* * *}\end{array}$ & & $\begin{array}{c}0.149 \\
(0.211)^{n . s .}\end{array}$ & & $\begin{array}{c}0.472 \\
(0.07)^{* * *}\end{array}$ & & $\begin{array}{c}0.145 \\
(0.160)^{n . s .}\end{array}$ \\
\hline Laissez- faire leadership & & & $\begin{array}{c}0.359 \\
(0.07)^{* * *}\end{array}$ & $\begin{array}{c}0.218 \\
(0.196)^{\text {n.s. }}\end{array}$ & & & $\begin{array}{c}0.419 \\
(0.09)^{* * *}\end{array}$ & $\begin{array}{c}0.272 \\
(0.156)^{\text {n.s. }}\end{array}$ \\
\hline
\end{tabular}

Note: The first value is the parameter estimate and the value in parentheses is the standard error (SE).

$\mathrm{N}$ (individuals) $=234 ; \mathrm{N}$ (teams) $=37$

$* \mathrm{p}<0.05, \quad * * \mathrm{p}<0.01, \quad * * * \mathrm{p}<0.001 \quad$ n.s. $=$ not significance 
According to the results, the transformational, transactional and laissez-faire leadership styles of the head in department were positively related to the in-role and extra-role performances of the administrative staff when analyzed separately by implementing multi-level analysis. This proved that the head of department who practiced transformational, transactional and laissez-faire leadership styles had a positive impact on the in-role and extra-role performances of the administrative staff. The findings from the current study are consistent with the previous study by Megat Zuhairy et al., (2015) which stated that in the field of leadership study, scholars had identified several leadership styles that showed a great influence on the organization.

Interestingly, when the transformational, transactional and laissez- faire leadership styles of the head of department were analyzed simultaneously, only the transformational leadership showed more influence or dominance on the extra-role performance of administrative staff compared to the transactional and laissez-faire leadership styles. These findings clarified that the transformational, transactional and laissez-faire leadership styles of the head of department were involved in increasing the in-role and extra-role performances of the administrative staff, but the head of department who adopted transformational leadership had more influence on the extra-role performance of the administrative staff compared to the transactional and laissez-faire leadership styles.

This is likely because the head of department who adopted transformational leadership constantly motivated the administrative staff members to perform their duties and should not favor self-interest for the common good and this in turn will increase the extra-role performance (Avolio \& Yammarino, 2002) compared to transactional leadership which focuses on the task-related exchange of actions and rewards between followers and leaders, and often needs the existence of hierarchy and authority to be displayed (Tyssen, Wald \& Heidenreich, 2014) and also laissez- faire leadership whereby the leader avoids active participation in the responsibility of goals setting and refuses to get involved when leadership direction is needed (Ejimabo, 2015). The findings were also supported by Gottfredson and Aguinis (2017), who state that transformational leadership seems to be the most effective and dominant concept in leadership research; additionally, transformational leadership style is more effective and preferred by leaders compared to other leadership styles (Egan, Sarros, \& Santora, 1995).

\section{Conclusion}

This present study clearly stated that transformational leadership styles of the head of department can the influence on performance of administrative staffs especially in extra-role performance. In summary, the present study offers valuable insights to head of department as a practitioners and also to policy makers. Practically, this study highlighted the importance of the head of department to choose the appropriate leadership style as it is play vital roles in increasing staff performance. Theoretically, this study adds value to the existing literature and to the body of knowledge to the field of leadership research by bringing up that the transformational leadership style as it was critical for achieving administrative staff performance especially for the extra-role performance. Finally, these variables deserve more attention for future research and should also employ and combine other variables in order to enrich the literature in this field of study. For example, future study can 
INTERNATIONAL JOURNAL OF ACADEMIC RESEARCH IN BUSINESS AND SOCIAL SCIENCES

Vol. 9, No. 3, March, 2019, E-ISSN: 222 2-6990 ¿ 2019 HRMARS

use motivating factors such as work engagement and self-efficacy as a mediating variable in order to explain the relationship within leadership style and performance.

\section{Acknowledgement}

Sincere thanks to the Universiti Pendidikan Sultan Idris for providing the funding for this project under Geran Pendidikan Universiti (Research Code: 2017-0162-106-01). Special thank goes to administrative staffs in one of the Premier Education University in Malaysia for their support and contributions.

\section{Corresponding Author}

Suzyanty Binti Mohd Shokory

Lecturer

Universiti Pendidikan Sultan Idris

35900, Tanjung Malim, Perak

Malaysia

Email: suzyanty@fpe.upsi.edu.my

\section{References}

Ahsan, N., Abdullah, Z., Fie, D.Y.G., \& Alam, S. S. (2009). A study of job stress on job satisfaction among university staff in Malaysia : Empirical study. European Journal of Social Sciences, 8(1), 121-131.

Avolio, B. J., \& Yammarino, F. J. (2002). Transformational and charismatic leadership. The road ahead. Monographs in Leadership and Management. (Vol. 2). St. Louis. https://doi.org/10.1108/S14793571(2013)0000005005

Bass, B. M., \& Avolio, B. (2000). Technical report, leader form, rater form and scoring key for the MLQ f\Form 5X-short. Redwood City, CA.

Bass, B., \& Avolio, B. (1995). Multifactor leadership questionnaire technical report. Redwood City, CA. Bass, B. M. (1985). Leadership and performance beyond expectations. New York: Free Press.

Bass, B., \& Riggio, R. E. (2006). Transformational leadership. Mahwah, NJ: Lawrence Earlbaum Associates.

Burns J.M. (1978). Leadership. New York: New York: Harper \& Row.

Dumdum, U.R., Lowe, K.B., \& Avolio, B. J. (2002). A meta-analysis of transformational and transactional leadership correlates of effectiveness and satisfaction: An update and extension. Transformational and Charismatic Leadership: The Road Ahead, 2(35-66).

Eagly, A.C., Johannesen-Schmidt, M.C., \& Van Engen, M. L. (2003). Transformational, transactional, and laissez-faire leadership styles: A meta-analysis comparing women and men. Psychological Bulletin, 129(4), 569-591. https://doi.org/10.1037/0033-2909.129.4.569

Egan, R., Sarros, J., \& Santora, J. (1995). Putting transactional and transformational leadership into practice. Journal of Leadership Studies, 2(3), 100-123. https://doi.org/https://doi.org/10.1177/107179199500200309

Ejimabo, N. O. (2015). An approach to understanding leadership decision making in organisation. European Scientific Journal, 11(11), 1-24. https://doi.org/10.1021/ja00032a032 
INTERNATIONAL JOURNAL OF ACADEMIC RESEARCH IN BUSINESS AND SOCIAL SCIENCES

Vol. 9, No. 3, March, 2019, E-ISSN: 222 2-6990 @ 2019 HRMARS

Fry, L. W. (2003). Toward a theory of spiritual leadership. Leadership Quarterly, 14(6), 693-727. https://doi.org/10.1016/j.leaqua.2003.09.001

Goodman, S. A., \& Svyantek, D. J. (1999). Person- organization fit and contextual performance : Do shared values matter $1,275,254-275$.

Gottfredson, R. K., \& Aguinis, H. (2017). Leadership behaviors and follower performance: Deductive and inductive examination of theoretical rationales and underlying mechanisms. Journal of Organizational Behavior, 38(4), 558-591. https://doi.org/10.1002/job.2152

Hirtz, P. D., Murray, S. L., \& Riordan, C. A. (2007). The effects of leadership on quality. EMJ Engineering Management Journal, 22-27. https://doi.org/10.1080/10429247.2007.11431718

Kreft, I.G., \& De Leeuw, J. (1998). Introducing multilevel modeling. Sage.

Long, C.S., \& Thean, L. Y. (2011). Relationship between leadership style, job satisfaction and employees' turnover intention: A literature review. Research Journal of Business Management, 5, 91-100.

Koech P.M., \& Namusonge, G.S. (2012). The effect of leadership styles on organizational performance at state corporations in Kenya. International Journal of Business and Commerce, 2(1), 1-12. https://doi.org/10.1109/IECON.2009.5414689

Maas, C. J., \& Hox, J. (2005). Sufficient sample sizes for multilevel modeling. Journal of Research Methods for the Behavioral and Social Sciences, 1, 86-92. https://doi.org/10.1027/16141881.1.3.86

Mathieu, J.E., \& Taylor, S. R. (2007). A framework for testing meso-mediational relationships in organizational behavior. Journal of Organizational Behaviour, 28(2), 141-172.

Motowidlo, S. J., \& Van Scotter, J. R. (1994). Evidence that task performance should be distinguished from contextual performance. Journal of Applied Psychology, 79(4), 475-480. https://doi.org/10.1037/0021-9010.79.4.475

Northouse, P. G. (2010). Leadership, theory and practice (5 th ed.). Thousand Oaks, CA: Sage Publications.

Obiwuru, T., Okwu, A., \& Akpa, V. (2011). Effects of leadership style on organizational performance: A survey of selected small scale enterprises in Ikosi-Ketu council development area of Lagos state, Nigeria. Australian Journal of Business and Management Research, 1(7), 100-111.

Piccolo, R.F., \& Colquitt, J. A. (2006). Transformational leadership and job behaviors: The mediating role of core job characteristics. Academy of Management Journal, 49(2), 327-340.

Posdakoff, P. M., \& MacKenzie, S. B. (1994). Organizational citizenship behaviors and sales unit effectiveness. Journal of Marketing Research, 31(3), 351-363. https://doi.org/10.1177/014920630002600307

Raudenbush, S., Bryk, A., \& Congdon, R. (2005). HLM: Hierarchical linear and nonlinear modeling (Version 6.04). Lincolnwood, IL: Scientific Software International.

Raudenbush, S.W., Bryk, A.S., Cheong, Y.F., Congdon, R., \& Du Toit, M. (2011). HLM 5177: Hierarchical linear \& nonlinear modeling. Lincolnwood: Scientific Software International, Inc.

Raudenbush, S.W., Bryk, A.S., Cheong, Y.F., \& Congdon, R. (2004). HLM6.01: Hierarchical linear and nonlinear modeling [software]. Lincolnwood, IL: Scientific Software International.

Sabharwal, M., \& Corley, E. A. (2009). Faculty job satisfaction across gender and discipline. Social 
Science Journal, 46(3), 539-556. https://doi.org/10.1016/j.soscij.2009.04.015

Tetteh, E. N., \& Brenyah, R. S. (2016). Organizational leadership styles and their impact on employees' job satisfaction: Evidence from the mobile telecommunications sector of Ghana. Global Journal of Human Resource Management, 4(4), 12-24.

Thacker, R.A., \& Holl, K. B. (2008). The impact of transformational leadership on organizational and leadership effectiveness. Journal of Management Development, 27(7), 708-726. https://doi.org/10.1108/02621710810883616

Tyssen, A. K., Wald, A., \& Heidenreich, S. (2014). Leadership in the context of temporary organizations: A study on the effects of transactional and transformational leadership on followers' commitment in projects. Project Management Journal, 21(3), 376-393. https://doi.org/10.1177/1548051813502086

Walumbwa, F. O., \& Hartnell, C. A. (2011). Understanding transformational leadership-employee performance links: The role of relational identification and self-efficacy. Journal of Occupational and Organizational Psychology, 84(1), 153-172. https://doi.org/10.1348/096317910X485818

Yammarino, F. J., \& Dansereau, F. (2008). Multi-level nature of and multi-level approaches to leadership. Leadership Quarterly, 19(2), 135-141. https://doi.org/10.1016/j.leaqua.2008.01.001

Yang, L.-R., Wu, K.-S., \& Huang, C.-F. (2013). Validation of a model measuring the effect of a project manager's leadership style on project performance. KSCE Journal of Civil Engineering, 17(2), 271-280. https://doi.org/10.1007/s12205-013-1489-0 